\title{
PERTUMBUHAN DAN HASIL DELAPAN GENOTIPE JAGUNG MANIS YANG DIBUDIDAYAKAN SECARA ORGANIK DI LAHAN RAWA LEBAK
}

\author{
Rimma Ita Hutasoit ${ }^{1}$, Mohammad Chozin ${ }^{1}$, Nanik Setyowati ${ }^{*}$ \\ ${ }^{1}$ Program Studi Agroekoteknologi, Fakultas Pertanian Universitas Bengkulu \\ * Corresponding Author: nsetyowati@unib.ac.id
}

\begin{abstract}
[GROWTH AND YIELD OF EIGHT SWEET CORN GENOTIPE ORGANICALLY GROWN IN SWAMPLAND]. Sweet corn (Zea mays saccharata Sturt) has a greater advantage than feed corn because of its early maturity and the price is more expensive. Recently, the need for sweet corn is higher than its production. To overcome these problems, it is necessary to expand the planting area by utilizing sub-optimal land such as swamps of low fertility. Agricultural intensification can be carried out through the use of organic materials to meet nutrient needs for growth and yield of sweet corn. Determination of varieties suitable for planting in sub-optimal land is also an effort to increase the productivity of sweet corn in swampland. This study aims to determine the potential of sweet corn genotype for organically cultivated in swampland. The material used in this study consisted of seven sweet corn genotypes and one comparative variety planted in experimental plots based on a Randomized Completely Block Design (RCBD) with three replications. The variables evaluated in this study were the growth, development, yield, and yield components of sweet corn. The results showed that the 8 sweet corn genotypes tested had significantly different in plant height, number of leaves, number of rows of seeds per cob, and yields per plot. Caps 17 B x Caps 22 and Caps 3 x Caps 5 are genotypes that have better growth than the comparative variety. On the other hand, the yield and yield components of the comparative variety was higher among the other genotypes tested.
\end{abstract}

Keyword: genotipe, organic, swampland, sweet corn, Zea mays

\begin{abstract}
ABSTRAK
Jagung manis (Zea mays saccharata Sturt) merupakan komoditas yang dapat memberikan keuntungan besar terhadap pertanian dibandingkan jagung biasa, karena nilai jual yang tinggi dan umur yang lebih genjah. Kebutuhan jagung manis tidak diimbangi dengan produksi. Upaya yang dilakukan adalah perluasan areal tanam dengan memanfaatkan lahan sub-optimal seperti rawa lebak memiliki kesuburan tanah yang rendah. Upaya intenfikasi dapat ditempuh dengan penggunaan bahan organik untuk memenuhi kebutuhan unsur hara dalam pertumbuhan dan hasil jagung manis. Pemilihan varietas yang sesuai terhadap lahan sub optimal juga merupakan upaya lain yang dapat digunakan untuk meningkatkan produktifitas jagung manis pada lahan rawa lebak.Penelitian ini bertujuan untuk menentukan genotipe jagung manis yang potensial dibudidayakan secara organik pada lahan rawa lebak. Bahan tanam yang digunakan adalah tujuh genotipe jagung manis dan satu varietas pembanding yang ditanam pada petak-petak percobaan berdasarkan Rancangan Acak Kelompok Lengkap (RAKL) dengan tiga ulangan. Pengamatan dilakukan terhadap komponen pertumbuhan, perkembangan, hasil, dan komponen hasil. Hasil analisis varians menunjukkan bahwa 8 genotipe jagung manis yang diuji, memiliki keragaman yang nyata pada tinggi tanaman, jumlah daun, jumlah baris biji per tongkol dan hasil per petak. Berdasarkan hasil evaluasi terhadap genotipe-genotipe tersebut, Caps 17 B x Caps 22 dan Caps 3 x Caps 5, merupakan genotipe yang memiliki pertumbuhan lebih baik dari varietas pembanding, sedangkan untuk hasil dan komponen hasil varietas pembanding menunjukkan hasil yang lebih tinggi diantara genotipe yang lain.
\end{abstract}

Kata kunci: jagung manis, Zea mays, pertanian organik, rawa lebak 


\section{PENDAHULUAN}

Jagung manis (Zea mays saccharata Sturt) mulai dikenal di Indonesia sejak tahun 1970. Jagung manis semakin populer dan banyak dikonsumsi karena memiliki rasa yang lebih manis dibandingkan jagung biasa. Kadar gula pada endosperm jagung manis sebesar 5$6 \%$ dan kadar pati $10-11 \%$, sedangkan kadar gula pada jagung biasa hanya $2-3 \%$ atau setengah dari kadar gula jagung manis (Sirajuddin, 2010). Jagung manis merupakan tanaman serba guna karena biji jagung manis yang masih muda dapat dimanfaatkan sebagai sayuran dan berbagai macam olahan makanan, sedangkan tongkol yang masih muda (babycorn) dapat dimanfaatkan sebagai sayuran. Beberapa bagian tanaman juga dapat dimanfaatkan di antaranya batang dan daun segar (setelah panen) untuk pakan ternak dan pupuk hijau/kompos, sedangkan batang dan daun kering digunakan sebagai bahan bakar pengganti kayu bakar (Purwono \& Hartono, 2007).

Jagung manis memberikan keuntungan relatif tinggi bila dibudidayakan dengan baik. Tanaman jagung manis memiliki umur produksi lebih singkat/genjah yaitu umur panen 70-80 hari setelah tanam (hst) (Palungkun \& Asiani, 2004), dibandingkan dengan umur panen jagung biasa yaitu 95-110 hari (Riwandi et al., 2014). Jagung manis memiliki harga yang lebih tinggi. Hal ini disebabkan antara lain permintaan konsumen yang semakin meningkat.

Konsumsi jagung manis terus mengalami peningkatan seiring dengan bertambahnya jumlah penduduk dan pola konsumsi dalam bentuk segar (Syukur \& Rifianto, 2013). Produktifitas jagung manis di Indonesia tergolong rendah yaitu 8,31 ton/ha, sedangkan potensi hasil jagung manis dapat mencapai $14-18$ ton/ha (Muhsanati et al., 2008). Oleh karena itu peluang pengembangan atau peningkatan produksi jagung manis masih terbuka luas. Upaya peningkatan produksi jagung manis melalui perluasan areal tanaman semakin berkurang karena salah satu penyebabnya adalah dipergunakan untuk usaha tani lainnya. Peningkatan produksi menjadi perhatian utama karena pada saat ini lahan yang tersedia untuk perluasan areal tanam adalah lahan sub optimal seperti rawa lebak yang tersebar luas di beberapa wilayah Indonesia.

Lahan rawa adalah lahan yang sepanjang tahunnya selalu mengalami jenuh air, dicirikan dengan kondisi air dangkal hingga tergenang. Luas lahan rawa lebak di Indonesia diperkirakan mencapai 13,28 juta ha yang terdiri atas lebak dangkal 4.167 juta ha $(31,4 \%)$, lebak tengahan 6.075 juta ha $(45,7 \%)$, dan lebak dalam 3.038 juta ha $(22,9 \%)$, tersebar di Sumatera, Papua, dan Kalimantan (Suyamto et al., 2007).

Lahan rawa lebak dapat dikembangkan sebagai lahan jagung manis terutama pada saat musim kemarau (Waluyo et al., 2011). Rawa lebak umumnya kahat unsur P, Cu, Zn dan B. Ketersediaan P nya rendah sampai sangat rendah (Haryono et al, 2013). Hambatan yang dijumpai dalam budidaya pada lahan rawa lebak adalah tingkat kesuburan tanah yang rendah dan adanya zatzat yang bersifat meracun bagi tanah $\left(\mathrm{Al}, \mathrm{Fe}, \mathrm{SO}_{4}\right)$,

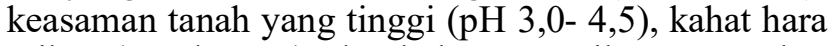
mikro ( $\mathrm{Cu}$ dan $\mathrm{Zn})$, dan bahan organik atau gambut mentah yang merupakan faktor penghambat bagi pertumbuhan tanaman (Helmi, 2015).

Upaya intensifikasi dapat ditempuh dengan penggunaan bahan organik untuk memenuhi kebutuhan unsur hara dalam pertumbuhan dan hasil jagung manis. Seiring dengan meningkatnya kesadaran masyarakat terhadap kesehatan dan kelestarian lingkungan, maka berkembang juga pertanian organik termasuk budidaya jagung manis. Jika budidaya jagung manis secara organik dilaksanakan pada lahan rawa lebak maka varietas yang dimaksud juga harus memiliki kemampuan untuk beradaptasi baik pada kondisi ketersediaan hara yang terbatas. Oleh karena itu varietas tanaman yang digunakan perlu memiliki mekanisme memanfaatkan hara secara efisien agar dapat beradaptasi pada ketersediaaan hara yang terbatas.

Saat ini varietas jagung manis tersedia, umumnya dirakit untuk pengembangan lahan dengan sistem budidaya konvensional, sehingga proses seleksi dalam program perakitannya perlu dilakukan pada lingkungan organik untuk memperoleh hasil yang optimum. Sebelum varietas jagung manis tersebut tersedia untuk masyarakat perlu dilakukan pengujian secara organik di berbagai kondisi lingkungan termasuk rawa lebak. Tujuan penelitian adalah menentukan genotipe jagung manis yang potensial dibudidayakan secara organik pada lahan rawa lebak.

\section{METODE PENELITIAN}

Penelitian dilaksanakan pada bulan Juli sampai bulan September 2018 di Desa Medan Baru, Kelurahan Kandang Limun, Kecamatan Muara Bangkahulu, Bengkulu. Lahan penelitian yang digunakan merupakan lahan rawa lebak dangkal berada pada ketinggian 10 $\mathrm{m}$ di atas permukaan laut.

Penelitian disusun menggunakan Rancangan Acak Kelompok Lengkap (RAKL) dengan satu faktor dan 3 ulangan, digunakan untuk menempatkan 8 genotipe jagung manis pada petak-petak percobaan berukuran $5 \mathrm{~m}$ x $0,7 \mathrm{~m}$. Genotipe yang dimaksud adalah yaitu Caps 2 x Caps 15, Caps 22 x Caps 17 B, Caps 5 x Caps 22, Caps 15 x Caps 22, Caps 3 x Caps 5, Caps 17 B x Caps 22, Caps 3 x Caps 22, dan varietas Bonanza sebagai pembanding.

Persiapan lahan dimulai dengan membersihkan lahan dari sisa tanaman dan gulma, kemudian diolah secara manual menggunakan cangkul hingga siap tanam. Selanjutnya lahan dibagi menjadi 3 blok (ulangan) dengan ukuran $5 \mathrm{~m}$ x $12 \mathrm{~m}$ dengan jarak antar blok $1 \mathrm{~m}$. Seminggu sebelum tanam tiap baris diberi pupuk kandang ayam dengan dosis 15 ton/ha atau setara dengan 5,25 
$\mathrm{kg} /$ petak.Penanaman dilakukan seminggu setelah penaburan pupuk kandang ayam dengan menempatkan benih dari tiap genotipe dalam barisan sesuai dengan hasil pengacakan. Menugal tanah sedalam $2 \mathrm{~cm}$ dengan jarak $30 \mathrm{~cm}$ dalam tiap barisan dan jarak antar barisan $70 \mathrm{~cm}$, kemudian mengisi 1 benih/ lobang tanam. Setiap genotipe menempati dua barisan, sehingga terdapat 32 tanaman dalam satu petak. Pemeliharaan tanaman meliputi pengairan, penyulaman, penyiangan dan pemupukan, pembumbunan, dan pengendalian Organisme Pengganggu Tanaman (OPT). Panen dilaksanakan ketika tanaman sudah menunjukkan kriteria panen, yaitu berumur 70-80 hst, ditandai dengan penampakan rambut luar mengering berwarna coklat kehitaman, tongkol keras bila digenggam, dan warna biji menguning.

Variabel yang diamati adalah tinggi tanaman, jumlah daun, diameter batang, umur berbunga jantan, umur berbunga betina, bobot tongkol berkelobot, diameter tongkol berkelobot, bobot tongkol tanpa kelobot, panjang tongkol tanpa kelobot, diameter tongkol tanpa kelobot, jumlah baris biji/tongkol, jumlah biji/ baris, jumlah tongkol/petak, dan hasil/petak.

Data hasil pengamatan dianalisis menggunakan varian (ANAVA) taraf $5 \%$. Data yang menunjukkan pengaruh nyata dianalisis lanjut dengan DNMRT (Duncan's New Multiple Range Test) pada taraf 5\%.

\section{HASIL DAN PEMBAHASAN}

Berdasarkan pertumbuhannya, populasi tanaman yang diteliti menunjukkan tingkat pertumbuhan yang normal, kecuali tinggi tanaman yang belum mencapai tingkat optimal dengan rata-rata hanya mencapai $179,4 \mathrm{~cm}$ (Tabel 1). Pada penelitian sebelumnya varietas Bonanza yang dibudidayakan secara organik memiliki tinggi tanaman rata-rata 226,68 (Samosir et al., 2015), bahkan dapat mencapai $247,25 \mathrm{~cm}$ ketika dibudidayakan secara konvensional (Suranto et al., 2015). Namun demikian, beberapa penelitian juga menunjukkan tinggi tanaman varietas Bonanza setara dengan yang diperoleh dalam hasil penelitian Syafii et al.(2014) yaitu 181,2 cm, dan hasil penelitian Jasman (2016) dengan tinggi tanaman $178,53 \mathrm{~cm}$.

Jumlah daun, berkisar antara 12 sampai 15 dengan rata-rata 14 juga umum dijumpai pada varietas Bonanza, bahkan termasuk banyak. Hasil penelitian Pangaribuan et al. (2017) menunjukkan, jumlah daun varietas Bonanza hanya memiliki rata-rata 11, sebaliknya rata-rata jumlah daun hasil penelitian Sitepu \& Adiwirman (2017) lebih banyak yaitu rata-rata 13 helai. Varietas Bonanza mampu menghasilkan 10-16 daun.

Diameter batang jagung yang dihasilkan berkisar antara $16 \mathrm{~mm}$ sampai $27 \mathrm{~mm}$ dengan rata-rata $21 \mathrm{~mm}$, juga termasuk berukuran sedang karena dalam deskripsi dinyatakan bahwa varietas Bonanza memiliki diameter batang antara $20 \mathrm{~mm}$ sampai $30 \mathrm{~mm}$. Hasil penelitian pada varietas Bonanza yang dibudidayakan secara organik menunjukkan bahwa diameter batang tertinggi mencapai 22,07 mm (Seipin et al., 2016), sedangkan ketika dibudidayakan secara konvensional dapat mencapai 22,83 mm (Syafruddin et al., 2012).

Tabel 1. Penampilan umum delapan genotipe jagung manis

\begin{tabular}{|c|l|c|c|c|c|}
\hline \multicolumn{1}{|c|}{ Variabel } & Min & Maks & Rata-rata & KK (\%) \\
\hline No & Tinggi tanaman (cm) & 152,6 & 217,6 & 179,37 & 9 \\
\hline 2. & Jumlah daun (helai) & 12,2 & 15,4 & 13,76 & 5,8 \\
\hline 3. & Diameter batang (mm) & 16,4 & 27,3 & 21,2 & 12,22 \\
\hline 4. & Umur berbunga jantan (hst) & 42 & 51,8 & 46,38 & 5,48 \\
\hline 5. & Umur berbunga betina (hst) & 46 & 55 & 50,9 & 4,26 \\
\hline 6. & Bobot tongkol berkelobot (g) & 272,3 & 436,32 & 346,05 & 13,33 \\
\hline 7. & $\begin{array}{l}\text { Diameter tongkol berkelobot } \\
\text { (mm) }\end{array}$ & 52,64 & 61,98 & 56,25 & 5,08 \\
\hline 8. & $\begin{array}{l}\text { Bobot tongkol tanpa kelobot } \\
\text { (g) }\end{array}$ & 182,8 & 308,6 & 245,35 & 15,78 \\
\hline 9. & $\begin{array}{l}\text { Diameter tongkol tanpa } \\
\text { kelobot (mm) }\end{array}$ & 44,73 & 54,03 & 47,35 & 5,53 \\
\hline 10. & $\begin{array}{l}\text { Panjang tongkol tanpa } \\
\text { kelobot (cm) }\end{array}$ & 14,4 & 18,8 & 16,75 & 7,8 \\
\hline 11. & Jumlah baris bijiltongkol & 12,4 & 17 & 14,67 & 19,17 \\
\hline 12. & Jumlah bijilbaris & 31,8 & 46,4 & 36,54 & 9,17 \\
\hline 13. & Jumlah tongkolpetak & 18 & 36 & 25,83 & 15,8 \\
\hline 14 & Hasil petak (kg) & 5,5 & 11,12 & 7,32 & 18,93 \\
\hline & & & & \\
\hline
\end{tabular}

Pembungaan merupakan penanda peralihan antara fase vegetatif dan fase generatif. Pada tanaman jagung manis fase generatif ditandai dengan munculnya bunga betina yang berbentuk rambut tongkol (silk) dan bunga jantan yang berbentuk malai (tassel). Dalam penelitian ini bunga betina muncul pada kisaran antara 46 sampai 55 hari seetelah tanaman (hst) dengan rata-rata 51 hst. Varietas Bonanza menghasilkan bunga betina pada kisaran 55 hst sampai 60 hst, sehingga populasi yang dievaluasi secara umum termasuk cepat memasuki fase generatif. Hasil penelitian Novira et al. (2015) menunjukkan bunga betina muncul ketika tanaman berumur 55 hst. Sebagaimana umumnya bunga jantan muncul lebih awal dibanding kemunculan bunga betina (Wijaya et al., 2017). Dalam hal ini bunga jantan muncul sekitar 4 hari sebelum kemunculan bunga betina. Dengan perbedaan kemunculan kedua jenis bunga tersebut yang cukup dekat, proses penyerbukan akan dapat berlangsung secara optimal (Darjanto \& Satifah, 1990).

Hasil jagung manis diukur berdasarkan bobot tongkol berkelobot per satuan luas dan bobot tongkol ditentukan oleh ukuran tongkol yang dikenal dengan komponen hasil. Sementara kualitas tongkol ditentukan 
oleh bobot tongkol berkelobot, panjang tongkol, jumlah baris/tongkol, dan jumlah biji dalam satu baris. Dari segi hasil dengan kondisi normal pada penelitian ini bobot tongkol berkelobot jagung manis memiliki kisaran antara 272,34 g sampai 436,32 g dengan ratarata sebesar $346,05 \mathrm{~g}$. Dalam penelitan yang dilakukan secara organik bobot tongkol jagung manis yang dihasilkan lebih ringan berkisar 222,97 g jika dibandingkan dengan konvensional sebasar 285,00 g (Sumekar, 2016). Hasil penelitian Chozin et al. (2017) menunjukkan bahwa varietas Bonanza merupakan salah satu varietas yang dapat dikembangkan di Bengkulu. Varietas Bonanza yang dibudidayakan pada penelitian ini menghasilkan diameter tongkol tanpa kelobot berkisar $44,73 \mathrm{~mm}$ sampai $54,03 \mathrm{~mm}$ dengan rata-rata $47,35 \mathrm{~mm}$. Diameter tongkol tanpa kelobot dengan varietas yang sama juga diperoleh oleh hasil penelitian Yusri (2013) sebesar $43 \mathrm{~mm}$. Diameter tongkol berkelobot pada penelitian ini sebesar $58,09 \mathrm{~mm}$.

Hasil penelitian ini juga menunjukkan kisaran bobot tongkol tanpa kelobot mencapai 182,78 g sampai $308,6 \mathrm{~g}$ dan rata-rata sebesar $245,35 \mathrm{~g}$ dan pada penelitian yang dilakukan oleh Syafruddin et al. (2012) dengan menggunakan varietas yang sama dan pemberian pupuk NPK cair menghasilkan bobot tongkol tanpa kelobot jagung manis sebesar 217,78 g. Penelitian yang berbeda juga dilaporkan oleh Surtinah (2015) bahwa varietas Bonanza menghasilkan bobot tongkol tanpa kelobot sebesar $295 \mathrm{~g}$ yang dipanen pada umur 65 hari.

Hartati et al. (2016) melaporkan bahwa panjang tongkol tanpa kelobot varietas Bonanza mencapai $19,85 \mathrm{~cm}$. Sesuai dengan hal tersebut panjang tongkol tanpa kelobot memiliki selisih perbedaan dengan hasil penelitian kali ini yang berkisar 14,4 cm sampai $18,8 \mathrm{~cm}$ dengan rata-rata $16,75 \mathrm{~cm}$. Budidaya secara konvensional juga tidak menutupi adanya perbedaan ukuran yaitu 21,27 cm (Syafii et al ., 2014). Hasil penelitian Pamandungan et al. (2016) menunjukkan, varietas Bonanza menghasilkan jumlah baris biji per tongkol sebanyak 17,33 baris. Pada penelitian ini dengan menggunakan delapan genotipe sebagai perlakuan menghasilkan jumlah baris biji/tongkol berkisar 12,4 sampai 17 baris dengan rata-rata 14,67 baris. Jumlah baris biji/ tongkol tersebut sudah setara yaitu 14,25 dengan hasil penelitian Nainggolan \& Hapsoh (2017). Capaian ini sudah memenuhi deskripsi jagung manis varietas Bonanza yaitu 16 sampai 18 baris

Fase pengisian biji jagung manis merupakan fase penuaan atau fase akhir tanaman jagung manis yang digunakan untuk penyimpanan hasil fotosintesis dan penyerapan unsur hara. Pada penelitian ini tanaman jagung manis menghasilkan jumlah biji per baris berkisar 31,8 sampai 46,4 baris dengan rata-rata 36,54 baris. Semakin banyak biji yang terdapat pada tongkol maka akan mempengaruhi ukuran tongkol jagung manis. Sitepu \& Adiwirman (2017) melaporkan bahwa jumlah biji/baris dihasilkan sebanyak 38.53 baris. Demikian terhadap komponen hasil yang lain seperti jumlah tongkol/petak berkisar 18 sampai 36 dengan rata-rata 25,83. Apabila semakin banyak jumlah tongkol/petak maka akan meningkatkan hasil jagung manis. Pada penelitian ini terlihat bahwa hasil/petak mencapai kisaran antara 5,50 kg hingga $11,12 \mathrm{~kg}$ dengan rata-rata $7,32 \mathrm{~kg}$.

Dalam pemuliaan tanaman, keleluasaan seleksi akan diperoleh ketika genotipe yang digunakan memiliki keragaman yang penting pada karakter-karakter agronomis. Koefisien keragaman dibedakan menjadi tiga kategori yakni tinggi $=>20 \%$, sedang $=10 \%-20 \%$, dan rendah $=<10 \%$ (Steel \& Torrie, 1993). Dalam penelitian ini koefisien keragamannya termasuk dalam kategori sedang, dan yang terbesar terdapat pada variabel hasil/ petak $(\mathrm{KK}=18,93 \%)$, jumlah tongkol $(\mathrm{KK}=15,80 \%)$, bobot tongkol tanpa kelobot $(\mathrm{KK}=15,78 \%)$, bobot tongkol berkelobot $(\mathrm{KK}=13,33 \%)$ dan diameter batang $(\mathrm{KK}=12,22 \%)$ (Tabel 1). Kelima variabel tersebut merupakan bagian yang termasuk dalam komponen pertumbuhan dan hasil dari proses pertumbuhan dan sangat bergantung pada kondisi tanaman dari setiap fase-fase pertumbuhan yang dilewati. Proses pemilihan genotipe potensial masih tetap dapat dilakukan karena pertumbuhan tanaman jagung manis mampu memberikan kontribusi pada komponen hasil dan hasil jagung manis. Untuk karakter lainnya seperti tinggi tanaman, jumlah daun, umur berbunga jantan, umur berbunga betina, diameter tongkol berkelobot, panjang tongkol tanpa kelobot, diameter tongkol tanpa kelobot, jumlah baris/tongkol, dan jumlah biji/baris nilai KK yang dihasilkan termasuk kategori rendah. Tinggi rendahnya nilai koefisien keragaman suatu tanaman dapat dipengaruhi oleh variabel pengama$\tan$.

Hasil analisis varians menunjukkan bahwa delapan genotipe jagung manis yang diuji memiliki keragaman yang nyata pada tinggi tanaman, jumlah daun, jumlah biji/baris, dan hasil/petak (Tabel 2). Hal ini berarti bahwa secara umum genotipe yang diuji memiliki penampilan yang serupa untuk sebagian besar sifatnya. Adanya keragaman yang ditunjukkan oleh variabel-variabel tersebut maka dapat dilakukan pemilihan genotipe jagung manis yang potensial untuk dibudidayakan pada lahan rawa lebak.

Rata-rata tinggi tanaman dan jumlah daun dari delapan genotipe yang dievaluasi. Berdasarkan tinggi tanamannya, Caps 17 B x Caps 22 dan Caps 3 x Caps 22 merupakan hibrida dengan postur tanaman yang lebih tinggi diantara hibrida lainnya, sementara Caps 2 x Caps $17 \mathrm{~B}$ dan Caps 5 x Caps 22 cenderung memiliki postur yang lebih pendek (Tabel 3). Adapun keuntungan tanaman jagung manis yang memiliki postur yang lebih tinggi ialah penangkapan cahaya matahari untuk melakukan fotosintesis bisa semakin optimal sedangkan tanaman yang pendek kalah bersaing 
untuk memperoleh cahaya matahari. Keuntungan tanaman jagung manis yang memiliki postur pendek yaitu tahan rebah terutama bila ada angin kencang disertai hujan, sedangkan tanaman yang tinggi mudah mengalami rebah batang apabila terjadi angin kencang pada lingkungan makro dan mikro jagung manis. Pada penelitian sebelumnya yang dilakukan oleh Lorenza et al. (2016) menunjukkan bahwa tinggi tanaman jagung manis rata-rata mencapai $134,30 \mathrm{~cm}$ sampai $147,43 \mathrm{~cm}$.

Tabel 2. Nilai F-hitung hasil analisis varian beberapa variabel pada delapan genotipe jagung manis

\begin{tabular}{|c|c|c|c|c|}
\hline \multirow{2}{*}{ Variabel } & \multicolumn{4}{|c|}{ F-Hitung } \\
\hline & Blok & & Genotipe & \\
\hline Tinggi tanaman & 3,93 & $*$ & 7,53 & * \\
\hline Jumlah daun & 1,47 & ns & 4,22 & $*$ \\
\hline Diameter batang & 0,17 & ns & 1,05 & ns \\
\hline Umur berbunga jantan & 1 & ns & 1,53 & ns \\
\hline Umur berbunga betina & 1,19 & ns & 1,86 & ns \\
\hline Bobot tongkol berkelobot & 3,15 & ns & 2,16 & ns \\
\hline $\begin{array}{l}\text { Diameter tongkol } \\
\text { berkelobot }\end{array}$ & 3,86 & $*$ & 2,52 & ns \\
\hline $\begin{array}{l}\text { Bobot tongkol tanpa } \\
\text { kelobot }\end{array}$ & 1,18 & ns & 1,73 & ns \\
\hline $\begin{array}{l}\text { Diameter tongkol tanpa } \\
\text { kelobot }\end{array}$ & 2,54 & ns & 3,02 & ns \\
\hline $\begin{array}{l}\text { Panjang tongkol tanpa } \\
\text { kelobot }\end{array}$ & 3,4 & $*$ & 2,68 & ns \\
\hline Jumlah baris biji/tongkol & 0,53 & ns & 2,04 & ns \\
\hline Jumlah biji/baris & 3,94 & $*$ & 3,67 & $*$ \\
\hline Jumlah tongkol & 1,4 & ns & 1,48 & ns \\
\hline Hasil/petak (g) & 19,95 & $*$ & 10,42 & * \\
\hline
\end{tabular}

Keterangan : * berpengaruh nyata, ns berpengaruh tidak nyata

Terdapat korelasi antar sifat pada tanaman. Jumlah daun tanaman jagung berhubungan erat dengan tinggi tanamannya (kolerasi sifat tanaman). Hal ini dapat dilihat dari hasil penelitian yang dilakukan oleh Oktarina (2016), bahwa terdapat korelasi positif antara tinggi tanaman dengan jumlah daun $(\mathrm{r}=0,63)$. Namun demikian dalam penelitian ini hubungan tersebut tidak tercermin dari dua sifat tanaman tersebut. Perbedaan panjang ruas batang dapat menjadi penyebab ketidaksesuaian tersebut. Penelitian yang dilakukan oleh Lorenza et al. (2016) menunjukkan, tinggi tanaman berkorelasi cukup erat dengan diameter batang $(r=0,87)$
Tabel 3. Rata-rata penampilan komponen pertumbuhan genotipe jagung manis

\begin{tabular}{|c|c|c|}
\hline \multirow[b]{2}{*}{ Genotipe } & \multicolumn{2}{|c|}{ Variabel } \\
\hline & $\begin{array}{l}\text { Tinggi } \\
\text { Tanaman }(\mathrm{cm})\end{array}$ & $\begin{array}{l}\text { Jumlah Daun } \\
\text { (helai) }\end{array}$ \\
\hline Caps 2 x Caps 15 & $172,2 \mathrm{bc}$ & $13,9 \mathrm{bc}$ \\
\hline Caps 2 x Caps 17B & $160,8 \mathrm{c}$ & $13,5 \mathrm{bc}$ \\
\hline Caps 5 x Caps 22 & $160,8 \mathrm{c}$ & $12,8 \mathrm{c}$ \\
\hline Caps $15 \mathrm{x}$ Caps 22 & $182,6 \mathrm{ab}$ & $13,1 \mathrm{bc}$ \\
\hline Caps $3 \times$ Caps 5 & $179,4 \mathrm{~b}$ & 15,0 a \\
\hline $\begin{array}{l}\text { Caps } 17 \text { B x Caps } \\
22\end{array}$ & 197,7 a & $13,9 \mathrm{bc}$ \\
\hline Caps $3 \times$ Caps 22 & 196,5 a & $13,8 \mathrm{bc}$ \\
\hline Bonanza & $184,9 \mathrm{ab}$ & $14,1 \mathrm{ab}$ \\
\hline \multicolumn{3}{|c|}{ Keterangan : angka-angka yang diikuti oleh huruf } \\
\hline \multicolumn{3}{|c|}{ yang sama pada kolom yang sama berbeda tidak } \\
\hline
\end{tabular}

Hal ini juga dapat dilihat bahwa tinggi tanaman juga mempengaruhi jumlah daun. Dalam penelitian ini tinggi tanamannya baik, sehingga jumlah daunnya sudah cukup banyak rata-rata 14 helai. Tanaman yang memiliki banyak daun pada umumnya akan semakin menguntungkan selama masa pertumbuhan vegetatif berlangsung terutama untuk memperoleh cahaya matahari.

Tinggi tanaman tertinggi diperoleh dari genotipe Caps 17 B x Caps $22(197,7 \mathrm{~cm})$. Pada kondisi lingkungan yang baik jagung manis mampu tumbuh optimum dengan tinggi tanaman mencapai $150 \mathrm{~cm}$ $250 \mathrm{~cm}$ (Riwandi et al., 2014). Sedangkan jumlah daun terbanyak dihasilkan oleh genotipe Caps $3 \mathrm{x}$ Caps 5 dengan jumlah 15 helai. Berdasarkan jumlah daun tanaman yang diteliti juga sudah sesuai dengan kriteria jumlah daun jagung manis pada umumnya yaitu 10-18 helai (Syukur \& Rifianto, 2013). Pada delapan genotipe jagung manis menunjukkan adanya perbedaan terhadap tinggi tanaman dan jumlah daun. Hal ini diduga, tanaman jagung manis memiliki susunan genetik yang tidak sama dan dengan kemampuan berbeda dalam beradaptasi pada lingkungan tumbuhnya, sehingga tetap menghasilkan pertumbuhan dan produksi yang maksimal. Hasil penelitian Ningsih et al. (2015) menunjukkan rata-rata tinggi tanaman dan jumlah daun pada beberapa varietas jagung manis sebesar $176,5 \mathrm{~cm}$ dan dengan jumlah daun sebanyak 10 helai. 
Secara umum, hibrida yang diuji memiliki keserupaan penampilan komponen hasil kecuali jumlah baris/tongkol. Rata-rata jumlah baris/tongkol menunjukkan bahwa Caps 5 x Caps 22, Caps 15 x Caps 22, Caps 3 x Caps 5, Caps 17 B x Caps 22, dan Caps 3 x Caps 22 memiliki jumlah baris biji/tongkol setara dengan varietas Bonanza yang digunakan sebagai pembanding (Tabel 4). Baris biji dalam tongkol jagung merupakan perkembangan dari rambut bunga betina yang bertempat pada tongkol yang biasanya dipengaruhi oleh proses penyerbukan dan pembentukan tongkol. Dengan demikian baris biji umumnya berjumlah genap, sedangkan jumlah ganjil dapat terjadi karena faktor genetik dan juga diameter tongkol, sehingga menyebabkan barisan biji jagung tumbuh melingkari tongkol jagung manis. Semakin besar diameter tongkol maka semakin besar peluang terbentuknya barisan biji pada tongkol.

Jumlah baris biji umumnya berkisar 10-18 baris (Syukur \& Rifianto, 2013). Hasil yang serupa juga didapat dalam penelitian ini dengan jumlah baris biji antara 14-16 baris, sedangkan Bonanza memiliki rata-rata sebanyak 16 baris. Dengan hasil ini jumlah baris biji/tongkol sudah memenuhi kriteria jagung manis pada umumnya. Jumlah baris biji/tongkol tanaman lebih dominan dikendalikan oleh faktor genetik tanaman jagung itu sendiri. Semakin banyak jumlah baris/tongkol maka semakin banyak juga jumlah biji/tongkol (Rahni, 2012). Jumlah baris biji juga berpengaruh terhadap hasil/petak yang akan diperoleh.

Tabel 4. Rata-rata penampilan komponen pertumbuhan delapan genotipe jagung manis

\begin{tabular}{l|c|c|}
\hline \multirow{2}{*}{ Genotipe } & \multicolumn{2}{|c}{ Variabel } \\
\cline { 2 - 3 } & $\begin{array}{c}\text { Jumlah baris } \\
\text { biji/tongkol }\end{array}$ & $\begin{array}{c}\text { Hasil/petak } \\
(\mathrm{kg})\end{array}$ \\
\hline Caps 2 x Caps 15 & $14,0 \mathrm{~b}$ & $6,1 \mathrm{~d}$ \\
\hline Caps 22 x Caps 17 B & $13,5 \mathrm{~b}$ & $6,6 \mathrm{~cd}$ \\
\hline Caps 5 x Caps 22 & $14,1 \mathrm{ab}$ & $6,5 \mathrm{~cd}$ \\
\hline Caps 15 x Caps 22 & $15,2 \mathrm{ab}$ & $6,8 \mathrm{~cd}$ \\
\hline Caps 3 x Caps 5 & $14,9 \mathrm{ab}$ & $7,9 \mathrm{~b}$ \\
\hline Caps 17 B x Caps 22 & 14,7 ab & $7,5 \mathrm{bc}$ \\
\hline Caps 3 x Caps 22 & $15,1 \mathrm{ab}$ & $7,6 \mathrm{bc}$ \\
\hline Bonanza & 15,9 a & $9,6 \mathrm{a}$ \\
\hline Keterangan : angka-angka yang diikuti oleh huruf \\
\hline yang sama pada kolom yang sama berbeda tidak \\
\hline nyata pada DNMRT 5\% & \\
\hline
\end{tabular}

Dalam penelitian ini hasil/petak merupakan bobot seluruh tongkol yang dapat dipasarkan dalam satu petak. Oleh karena setiap tanaman dapat saja menghasilkan lebih dari satu tongkol yang berkembang penuh, maka jumlah tongkol yang dapat dipasarkan juga dapat tidak sama. Calon varietas jagung manis yang mempunyai sifat prolifik (bertongkol lebih dari satu) yang sedang diuji di berbagai wilayah yang berbeda.

\section{KESIMPULAN}

Secara umum penampilan pertumbuhan dan hasil delapan genotipe jagung manis tumbuh baik pada lahan rawa lebak yang dibudidayakan secara organik. Pertumbuhan yang paling baik adalah genotipe Caps 17 B x Caps 22 dan Caps 3 x Caps 22, sedangkan untuk hasil tertinggi adalah varietas Bonanza.

\section{DAFTAR PUSTAKA}

Chozin, M., Sudjatmiko, S., Setyowati, N., Fahrurrozi, F. \& Muktamar, Z. (2017). Daya gabung karakteristik tongkol dari galur-galur inbrida jagung manis pada sistem budidaya organik. J. Hort. Indonesia, 8(1), 38-48.DOI: https://doi.org/ 10.29244/jhi.8.1.48-58.

Darjanto \& Satifah, S. (1990). Pengetahuan Dasar Biologi: Bunga dan Teknik Penyerbukan Silang Buatan. Gramedia, Jakarta.

Hartati, R., Yetti, H. \& Puspita, F. (2016). Pemberian trichokompos beberapa bahan organik terhadap pertumbuhan dan produksi jagung manis (Zea mays saccharata Sturt). Jurnal Online Mahasiswa Fakultas Pertanian Universitas Riau, 3(1), 1-15.

Haryono, Noor, M., Syahbuddin, H. \& Sarwani, M. (2013). Lahan Rawa:Penelitian dan Pengembangan. Badan Penelitian dan Pengembangan Pertanian. Kementerian Pertanian, Jakarta.

Helmi. (2015). Peningkatan Produktivitas Padi Lahan Rawa Lebak melalui Penggunaan Varietas Unggul Padi Rawa. Jurnal Pertanian Tropik, 2(2), 78-92.

Jasman. J. (2016). Pengaruh jarak tanam dan jumlah benih per lubang terhadap pertumbuhan dan hasil tanaman jagung manis (Zea mays saccarata Sturt L.). Skripsi. Fakultas Pertanian Universitas Teuku Umar Meulaboh, Aceh Barat.

Lorenza, E., Chozin, M. \& Setyowati, N. (2016). Hubungan antar sifat jagung manis yang dibudidayakan secara organik. Akta Agrosia, 19(2), 129-138. DOI: https://doi.org/10.31186/aa.19.2.129-138.

Muhsanati, Syarif, A. \& Rahayu, S. (2008). Pengaruh beberapa takaran kompos tithonia terhadap pertumbuhan dan hasil tanaman jagung manis (Zea mays saccharata). Jerami, 1(2), 87-91.

Nainggolan, G. \& Hapsoh (2017). Respons tanaman jagung manis (Zea mays saccharata Sturt) yang diberi pupuk guano dengan npk di lahan gambut. Jurnal Online Mahasiswa Fakultas Pertanian Universitas Riau, 4(2), 1-15.

Ningsih, N.D., Marlina, N. \& Hawayanti, E. (2015). Pengaruh jenis pupuk organik terhadap pertumbuhan 
dan produksi beberapa varietas jagung manis (Zea mays saccharata Sturt). Klorofil: Jurnal Penelitian Ilmu-Ilmu Pertanian, 10(2), 93-100.

Novira, F., Husnayetti \& Yoseva, S. (2015). Pemberian pupuk limbah cair biogas dan urea, TSP, $\mathrm{KCl}$ terhadap pertumbuhan dan produksi tanaman jagung manis (Zea mays saccharata Sturt.). Jurnal Online Mahasiswa Fakultas Pertanian Universitas Riau, 2(1), 1-15.

Oktarina, N. (2016). Korelasi genetik pertumbuhan dan Hasil 15 Jagung Hibrida. Skripsi. Program Studi Agroekoteknologi Fakultas Pertanian Universitas Bengkulu, Bengkulu.

Palungkun, R. \& Asiani, B.(2004). Sweet Corn-Baby Corn: Peluang Bisnis, Pembudidayaan dan Penanganan Pasca Panen. Penebar Swadaya, Jakarta.

Pamandungan, Y., Runtunuwu, D.S., Mamarimbing, R. \& Najoan, J. (2016). Pengelolaan pupuk terpadu dalam upaya meningkatkan hasil jagung manis dan kesuburan lahan pada sistem tanam jajar legowo. EUGENIA, 22(1), 38-46.

Pangaribuan, D.H., Hendarto, K. \& dan Prihartini, K. (2017). Pengaruh pemberian kombinasi pupuk anorganik tunggal dan pupuk hayati terhadap pertumbuhan dan produksi tanaman jagung manis (Zea mays saccharata Sturt) serta populasi mikroba tanah. Jurnal Floratek, 12(1), 1-9.

Purwono \& Hartono, R. (2007). Bertanam Jagung Unggul. Penebar Swadaya, Bogor.

Rahni, N.M. (2012). Karakteristik pertumbuhan dan hasil jagung (Zea maysL.) pada ultisols yang diberi pupuk hayati dan pupuk hijau. Jurnal Agriplus, 22(3), 62-169.

Riwandi., Handajaningsih, M. \& Hasanudin. (2014). Teknik Budidaya Jagung dengan Sistem Organik di Lahan Marjinal. UNIB Press. Bengkulu.

Samosir, A.T., Paulus, J.M., Sumampow, D.M. \& Tumbelaka, S. (2015). Pemberian kompos jerami padi terhadap pertumbuhan dan produksi tanaman jagung manis (Zea mays saccharata Sturt). Cocos: E-Journal, 6(12), 1-9.

Seipin, M., Sjofjan, J. \& Ariani, E. (2016). Pertumbuhan dan produksi tanaman jagung manis (Zea mays saccharata Sturt) pada lahan gambut yang diberi abu sekam padi dan trichokompos jerami padi. Jurnal Online Mahasiswa Fakultas Pertanian Universitas Riau, 3(2), 1-15.

Sirajuddin, M. (2010). Komponen hasil dan kadar gula jagung manis (Zea mays saccharata) terhadap pemberian nitrogen dan zat tumbuh hidrasil. Penelitian Mandiri. Fakultas Pertanian. Universitas Tadulako. Palu.

Sitepu, A. \& Adiwirman, A. (2017). Respon pertumbuhan dan produksi jagung manis (Zea mays
Var. saccharata Sturt) terhadap limbah padat pabrik kelapa sawit dan NPK. Jurnal Online Mahasiswa Fakultas Pertanian Universitas Riau,4(2),1-15.

Steel, R. G. D \& Torrie, J.H. (1993). Prinsip dan Prosedur Statistika (Pendekatan Biometrik). Diterjemahkan Sumantri, B. Gramedia Pustaka Utama, Jakarta.

Sumekar, Y. (2016). Pengaruh berbagai komposisi dosis kompos unpad dan pupuk buatan terhadap pertumbuhan dan hasil tanaman jagung manis (Zea mays saccharata L.) varietas Bonanza. Agros: Jurnal Agroteknologi dan Sains (Journal of Agrotechnology Science), 1(1), 57-66.

Suranto, H., Sjofjan, J. dan Yoseva, S. (2015). Pemberian abu sekam padi dengan pupuk NPK terhadap pertumbuhan dan produksi tanaman jagung manis (Zea mays saccharata Sturt) pada tanah gambut. Jurnal Online Mahasiswa Fakultas Pertanian Universitas Riau, 2(1), 1-15.

Suyamto, Pane, H., Suwarno, Kustianto, B., Makarim, K., Suharto, H.\& Sembiring, H.(2007). Pengelolaan Tanaman Terpadu (PTT) Padi Lahan Rawa Lebak. Badan Penelitian dan Pengembangan Pertanian, Departemen Pertanian, Jakarta.

Surtinah, S. (2015). Pengujian tiga varietas jagung manis (zea mays saccharata) di rumbai kota Pekanbaru. Jurnal Ilmiah Pertanian, 12(1), 37-43.

Syafii, M., Murniati \& Ariani, E. (2014). Aplikasi kompos serasah jagung dengan bahan pengkaya terhadap pertumbuhan dan produksi tanaman jagung manis (Zea mays saccharata Sturt). Jurnal Online Mahasiswa Faperta, Universitas Riau, 1(2), 1- 8

Syafruddin, S., Nurhayati,N. \& Wati, R. (2012). Pengaruh jenis pupuk terhadap pertumbuhan dan hasil beberapa varietas jagung manis. Jurnal Floratek, 7(1), 107-114.

Syukur, M .\& Rifianto, A. (2013). Jagung Manis. Penebar Swadaya, Jakarta.

Waluyo, W., Suparwoto, S. \& Sudaryanto, S. (2011). Fluktuasi genangan air lahan rawa lebak dan manfaatnya bagi bidang pertanian di Ogan Komering Ilir. Jurnal Hidrosfir Indonesia, 3(2), 57-66.

Wijaya, R.A., Badal, B. \& Novia, P. (2017). Pengaruh takaran bokashi kotoran sapi terhadap pertumbuhan dan hasil tanaman jagung manis (Zea mays saccharata). UNES Journal Mahasiswa Pertanian, 1(1), 54-62.

Yusri, N. (2013). Pengaruh jarak tanam dan dosis pupuk NPK terhadap pertumbuhan dan hasil tanaman jagung manis (Zea mays saccharata Sturt). Doctoral Dissertation, Universitas Teuku Umar Meulaboh, Aceh. 